\title{
The History of a Magazine Is But the Influence of a Great Man? Thomas Carlyle and the Decline of "Fraser's Magazine"
}

\section{Christiane Hadamitzky}

When one looks for those 'eminent Victorians' who shaped the intellectual life of the $19^{\text {th }}$ century, Thomas Carlyle always makes the list. As a writer, he contributed works to many aspects of political and social life and was regarded as one of the great thinkers of his time. As influential and progressive as many of his ideas were, some of his opinions, such as his scepticism towards the theory of evolution or his belief that the ruling of the masses by a select few should be favoured over democratic tendencies, had fallen behind the times by the last quarter of the $19^{\text {th }}$ century. Nevertheless, the writer and his political orientation had supporters, such as the monthly publication "Fraser's Magazine", which found a kind of figurehead in Carlyle. While society was changing rapidly in the second half of the $19^{\text {th }}$ century, the magazine held on to Thomas Carlyle as its publicist hero, thereby losing touch with its audience and finally being unable to find enough readers for the publication to be continued. In the following, I am going to use Carlyle's theory of heroism as an example to trace the inability of the magazine to face the requirements of the contemporary popular print market and its readers.

\section{"Fraser's Magazine" and the Success of Its Early Years}

The story of the founding of "Fraser's Magazine" is well known and has almost turned into legend; in 1830, William Maginn, the Irish writer who was to become a sort of leader to his fellow 'Fraserians' in the first decade of the publication, was looking for a forum to voice his opinion. He had long been writing for "Blackwood's", but his articles were refused more and more often for their candour and boldness, and Maginn had to find new ways to reach an audience. Thus, as Walter Houghton narrates the incident, "with a roll of manuscript under his arm, Maginn and his friend Hugh Fraser, possessor of the required cash, were walking down Regent Street [...] when they came to the shop of James Fraser the publisher and Maginn exclaimed 'Fraser! Here's a namesake of yours. Let's try him.' By great luck the publisher was just then thinking of trying a monthly ma- 
gazine that would be both popular and scholarly [...] and a periodical named after Hugh Fraser began publication in February 1830". ${ }^{1}$

The magazine's main emphasis, so the Wellesley Index describes, lay on "politics, religion, and social conditions, in contrast to journals like the Cornbill or Temple Bar [for the early years, "Blackwood's" could be added here], so largely devoted to literature and literary criticism". ${ }^{2}$ This does not, however, hold true completely, since the magazine printed a large number of reviews and also literary works (for example, novels by Thackeray or Carlyle) and one of its most successful series in the early years, which was also representative of the tone of "Fraser's Magazine" under Maginn as a whole, was "The Gallery of Illustrious Literary Characters". The series portrayed contemporary figures in the literary field, both those whom the authors thought to be extraordinarily good, as well as those whom they disliked. ${ }^{3}$

The first issue of the magazine opened with a "Confession of Faith", ${ }^{4}$ in which Maginn characterises the magazine and also indirectly states which kind of audience he is looking for: "Our political tendencies will be sufficiently apparent to the intelligent from what we have said already; - to the non-intelligent it would be useless to address ourselves". ${ }^{5}$ The "confession" then goes on to address several topics, such as religion, foreign policy, domestic policy and other current fields of interest, but always stays quite abstract. Thus, from the very first issue Maginn not only voices his opinion straightforwardly but demands readers to think for themselves. What made "Fraser's" stand out was on the one hand the indeed fearless way in which it dealt with current issues and the people involved, and on the other hand the competence expected from the readers. The articles, which were mostly essays, were seldom shorter than fifteen pages, frequently twenty-five to thirty pages, and thus required readers to be fully literate, ${ }^{6}$ intelligent, informed on current topics and able to reflect on them in order to handle the frequent sarcasm with which the topics were treated.

This targeting of the magazine at an educated, conservative, intellectual middle and upper class is further emphasised by the fact that, unlike many other magazines, "Fraser's" did not include illustrations but focussed solely on text,

1 W. E. Houghton (ed.), The Wellesley Index to Victorian Periodicals 1824-1900, Vol. 2, Toronto 1972, p. 304.

2 Ibid.

3 The most well-known of these is probably the article and accompanying caricature of Harriet Martineau, who is depicted as a witch-like character sitting in front of a fireplace surrounded by cats with a mad look on her face. Other women, such as Letitia Elizabeth Landon, are depicted in more 'flattering' terms, which means that they are described and painted in accordance with the gender-norms of their time.

4 Our Confession of Faith, in: Fraser's Magazine, February 1830, p. 4.

5 Ibid.

6 In contrast to that, many popular periodicals were - as has often been suggested - especially designed to appeal to both advanced readers as well as to those who had some trouble reading longer texts, thus often producing short, anecdotal articles. 
with the aforementioned "Gallery of Illustrious Literary Characters" with its satirical portraits being the rare exception. The target audience was also reflected in the price of the magazine, which, at $2 \mathrm{~s} 6 \mathrm{~d}$ per monthly issue, ranked among the more expensive periodicals. Due to these characteristics, the magazine was, according to Miriam Thrall, ${ }^{7}$ one of the most "powerful weapons of personal and political warfare that the press has devised". 8

Since "Fraser's" was not afraid to publish frank comments on political and literary activities, many of the frequent contributors joined "Fraser's" not primarily out of economic necessity but out of curiosity and fascination. ${ }^{9}$ This holds true for Thomas Carlyle, whose influence on and reception in the magazine will be examined in the following.

\section{Thomas Carlyle's Relationship to "Fraser's Magazine"}

Carlyle was intrigued by the magazine from the beginning and wrote to his brother in September 1830: "Fraser's Magazine" is "a strange magazine, all full of Maginnism, yet with many good things. [...] [T] ell me if you can who manages it, who writes in it; how it works and has its being". ${ }^{10}$ Having acquired information about the magazine's representatives, he submitted a few essays and soon became a regular contributor to "Fraser's". However, it is not easy to determine exactly how many articles can be attributed to Carlyle, since not all of his work appeared under his name in the pages of the magazine. Due to the lack of secondary material, there is still no comprehensive list of articles by Carlyle in "Fraser's". 11 Thus, one can only rely on the few articles signed by Carlyle, those iden-

7 Miriam Thrall's 1934 study remains the only monograph on "Fraser's Magazine" and provides, although sometimes a bit tainted by an admiration for Maginn and the group surrounding him, much information on the contributors, topics dealt with and the sociocultural context of the 1830s and 1840s. Further valuable work was conducted by Patrick Leary. However, most of the work up to now has focussed on the important early decades of the magazine or, if exceeding that period, on specific figures involved, such as the contributions of Disraeli or Thackeray. Hence, a more general account for the later years of the magazine is still missing.

8 M. M. H. Thrall, Rebellious Fraser's: Nol Yorke's Magazine in the Days of Maginn, Thackeray, and Carlyle, New York 1934, p. 13.

9 Thomas Carlyle and William Thackeray are only the most prominent examples of this. For a more detailed account of early-year contributors, see Thrall, Rebellious Fraser's (footnote 8).

10 Qtd. in P. Leary, Fraser's Magazine and the Literary Life, 1830-1847, in: Victorian Periodicals Review 27, Issue 2, 1994, pp. 105-126, here p. 105.

11 An attempt has been made in the article "A Phase of Carlyle's relation to Fraser's Magazine", again by Miriam Thrall, to link some anonymous articles to Carlyle and to exclude others; however, Thrall mainly relies on what Shine calls "internal evidence", H. Shine, Articles in Fraser's Magazine Attributed to Carlyle, in: Modern Language Notes 51, Issue 3, 1936, pp. 142-145, here p. 145, which passages like the following illustrate: "[The articles] either acknowledge the overlordship of Schelling and Schlegel too servilely to have come from the pen of Carlyle, or they contain too great an admixture of Coleridge's doctrines", Thrall, Rebellious Fraser's (footnote 8), p. 922. Thus, Thrall tries to find evidence for 
tified in the Wellesley Index and those mentioned in letters between Carlyle, Fraser and others in which he discusses his work for the magazine.

Judging by those articles which can be attributed to Carlyle, he mostly wrote reviews, essays and only occasionally fiction for the magazine. He "published essays on Goethe, Schiller, 'Boswell's Life of Johnson,' 'Biography,' 'Thoughts on History,' and in narrative 'The Diamond Necklace' and 'Count Cogliostro,' as well as Sartor [Resartus]". 12 "Sartor Resartus", published in instalments from 1833 to 1834, was the only major literary work of Carlyle's which appeared in "Fraser's" and was the work which put Carlyle's relation to the magazine to the test. The work was received quite negatively by the audience and, having initially thought about a book release, "Fraser's" decided not to publish it as a monograph since readers had already threatened to cancel their subscriptions if similar works were to appear again. ${ }^{13}$

However, the connection between the writer and the periodical remained and the belief placed in the aspiring author Carlyle offered him security. As John Morrow, in his biography of Carlyle, points out:

"his association with Fraser's was very valuable financially and artistically. It gave him opportunities to experiment with unconventional literary styles and also provided an outlet through which he could participate in a literary sub culture that challenged the tradition of 'gentlemanly authors' from whom he wished to distinguish himself. The tone of Fraser's was both highly intellectual and outrageously (sometimes brutally) humorous, with 'Literary dandies', fashionable novelists such as Bulwer Lytton, as favourite targets."14

Indeed, the magazine offered Carlyle not only artistic but also financial freedom. Carlyle was, after a short time, paid more than all other contributors. Generally authors were paid per sheet, which consisted of sixteen pages. For his early contributions Carlyle received $£ 15$ per sheet, after 1835 even $£ 20 .{ }^{15}$ In comparison, Thackeray received $£ 10$ per sheet, Carlyle’s brother John only £7. Thus, Carlyle had made himself the best paid contributor to the magazine in only a few years. ${ }^{16}$

But the relationship between Carlyle and "Fraser's" was maintained not only out of necessity. As Carlyle put it in a letter to Mills, "Fraser's", in the early years of his career, was his "best speaking mechanism". ${ }^{17}$ And in a letter to Fraser he writes

Carlyle's authorship from the articles' style and from their topics. In some cases, this comes close to mere conjecture when Thrall, for example, believes to be able to identify authors imitating Carlyle and drawing on his topics.

12 Houghton, The Wellesley Index (footnote 1), p. 309.

13 Ibid., p. 71.

14 J. Morrow, Thomas Carlyle, London 2006, p. 42.

15 Leary, Fraser's Magazine (footnote 10), p. 109.

16 He exerted this increased influence also in regard to his articles. For example, he refused the "compromising drudgery of reviewing" after a while and mostly submitted essays. Also, he began to fight for an "effective regime of copyright protection", Morrow, Thomas Carlyle (footnote 14), p. 42, which would make him more independent from publishers.

17 Carlyle qtd. in Morrow, Thomas Carlyle (footnote 14), p. 108. 
that he was fond of "much of its [the magazine's] spirit" and therefore "should decidedly wish to do business". ${ }^{18}$ What Carlyle possibly meant by the "spirit" of the magazine was its opinion regarding political and social questions. In this respect, parallels between the magazine and Carlyle are obvious, as Morrow points out:

"The issue that particularly concerned Carlyle at this time was widespread underemployment throughout Great Britain and a perception that significant sections of the lower classes were becoming pauperised. Articles on these and related themes had been a regular feature of Fraser's Magazine since its establishment in 1830."19

The political focus of Carlyle and "Fraser's" being compatible might have been a reason for Carlyle "decidedly" 20 wanting to publish in "Fraser's". On the other hand, Carlyle left a cultural imprint on the magazine himself. For example, he was the one to introduce German literature and the ideas of German transcendentalism to the magazine through his translations, which frequently reappeared as a recurring theme in the periodical, ${ }^{21}$ and those who put forward anti-utilitarian views in its pages frequently quoted him in support.

In connection to literary works, however, Carlyle did not play a major role in the magazine, as the reception of several published pieces was never overwhelming and the aforementioned negative reaction of readers to Carlyle's "Sator Resatrus" strained the relationship between writer and magazine for a while. ${ }^{22}$ And even in the years after his active involvement, the magazine only seldom refers to him as a literary writer and if so, he is mostly criticised for his complicated literary style, which made his works inaccessible to many readers. In relation to politics and history as well as moral and social questions, however, Carlyle, until the suspension of the magazine in 1882, remained a fixed reference point for the contributors of the magazine, as I will show in the following in relation to his lectures on heroism.

\section{"On Heroes, Hero-Worship and the Heroic in History" - Thomas Carlyle's Concept of Heroism}

Carlyle's theory of heroism was originally set out in a series of lectures, delivered in London in May 1840. In these lectures he outlines a general concept of heroism and hero-worship and develops six categories for 'his' heroes, then devoting a lecture to each 'type': the types he identifies are hero as divinity, as priest, as poet, as man of letters - an interesting category since he identifies the contemporary

18 Ibid., p. 42.

19 Ibid., p. 75.

20 Ibid., p. 42.

21 Cf. J. A. Froude, Froude's Life of Carlyle, London 1979, p. 275.

22 In fact, Carlyle had only published "Sator Resartus" in instalments in "Fraser's" because he had been unable to find a publisher to publish it as a book. 
print market as a new form of religion with "the writers of Newspapers, Pamphlets, Poems, Books" at its core ${ }^{23}$-, and lastly, hero as king. To summarise his notion of the heroic, one could say that a hero, as Carlyle illustrates with examples such as Mohammed, Shakespeare, Samuel Johnson, Cromwell or Napoleon, is someone with special insight into the world, a man who can see the reality behind idolatry and superficiality and - this is one of the most important points has a direct connection to the divine presence of God. He - women are not mentioned in Carlyle's lectures - has a genuine sincerity and truthfulness and tries to convey his insight into the world to others, tries to make them see what he sees and thus has the ability to change and shape the world. The hero's life is often marked by endurance; the true hero, however, proves his sincerity and genuine earnestness by devoting his life fully to his cause. The lectures were very popular at the time; a printed version - which was published by James Fraser - came out in 1841 and was successful with both intellectuals as well as the general reading public. $^{24}$

This concept of heroism soon found its way into "Fraser's" as well, and in the following I am going to use examples of the perpetual invocation of Carlyle's ideals after his time as a contributor to the journal to illustrate the magazine's inability to adapt to contemporary opinions and developments. Unable to keep up with the changing ideas of contemporary society as well as the changing demands of contemporary audiences, "Fraser's" was finally discontinued in 1882. After all, British society did not only see technological advances in the second half of the $19^{\text {th }}$ century but great social movements as well: people became increasingly prone to ideas of democracy and the individual grew in importance over the collective. This can also be seen in the contemporary discourse on heroes and heroism. While Carlyle and writers like Kingsley or the American thinker Emerson had propagated a collective search for a leader and a government of the elite, movements like positivism and not least the theory of evolution turned the idea of a chosen divine leadership into a mere thought experiment. These changes in thinking affected the general conception of heroism as well, leading to the idea that almost anybody can become a hero - although the field of action and range of influence might vary - through perseverance and dedication to individual selfimprovement. By failing to acknowledge these societal developments, "Fraser's" lost touch with the world around it and finally its readers as well.

In the following, I am going to analyse articles in "Fraser's Magazine" from the 1850 s, 60 s and 70 s, referring to Carlyle's concept of heroism, thereby show-

23 T. Carlyle, On Heroes, Hero-Worship, and the Heroic in History. Six Lectures: Reported With Emendations and Additions, London 1841 (Repr. Ann Arbor, MI 2006), p. 146.

24 In the second half of the $19^{\text {th }}$ century, many critics called the work Carlyle's "best known" one, partly for the reason that it was the "most readable" as well, D. Hodge, Carlyle, the Man and Teacher, Edinburgh 1875, p. 17. Similar views can be found in J. P. Boyd, Carlyle: His Writings and Characteristics, London 1850; E. P. Hood, Thomas Carlyle, Philosophic Thinker, Theologian, Historian, and Poet, London 1875. 
ing how the magazine clung to the mystic notion of its early-day "faith" and how traditional, conservative ideas and semantics prevailed throughout these decades of change.

\section{The Ideal Historian - the Reception of Thomas Carlyle in "Fraser's" in the Second Half of the 19th Century}

After his phase as an active writer for "Fraser's", Carlyle is mainly mentioned as a historian and moral guide in the magazine. Subsequently, a considerable number of references to his vision of heroic men also surfaced in contributions dealing with history and history writing. In many of these articles, the current state of history writing is discussed and a new 'class' of heroes in Carlyle's fashion is designed: the hero as historian. What unites all articles that reflect upon this 'hero as historian' is a general feeling of loss or inadequacy. All contributors convey a notion that history writing as conducted in England by the majority of historians is insufficient and done without proper competence. The tasks of the historian, as for example the author of a review on a history book by Arthur Helps in 1855 writes, have radically changed from "the easy-going days of Robertson and Hume". ${ }^{25}$ The author goes on to contrast 'classical' to 'modern' history and remarks:

"the modern public requires, and the modern historian is expected to supply, much that formerly was either not desired, or considered to belong to other departments of inquiry. The classical historians of antiquity were once regarded as the be-all and the end-all of narrative. [...] But at the present day the historian is expected to embody all these functions; [...] Instead therefore of moving on one main trunk line of conspicuous and stirring events, the writer of history is occupied, and sometimes even bewildered, by the collateral topics pressing on his notice, and discovers that even the most concise account of any great period or crisis assumes inevitably an encyclopaedic form and compass."26

The perceived fragmentation and increased complexity of modern life also affected history writing, as the contributor points out.

To be an expert in all of the above-named topics and still produce a text which is legible and relevant seems almost impossible, and therefore it is not surprising that the historians of the day appeared inadequate to the contributors for different reasons. On the one hand, they could be criticised for not adhering to all the requirements, not being able to touch upon all subjects, not being an expert on all facets of life at the particular point in history. On the other hand, the historians also had to face the opposite accusation; as the quotation above already hints at, a history text which tries to incorporate each and every detail of a period will most certainly be an illegible piece of writing which runs the risk of omitting or not sufficiently stressing the relevant things while giving details for areas which do not

25 Helps's Spanish Conquest in America, in: Fraser's Magazine, September 1855, p. 243.

26 Ibid. 
necessarily contribute to an understanding of the given time. ${ }^{27}$ Nevertheless, it is still important to note that a lack of sufficiency was attested in relation to the history writing of the day, whether the criticism complained of a lack of complexity or insufficient simplicity and skilful writing. Regardless of which side one chooses, there was a feeling that history writing as conducted around the mid-19th century did not contribute to a 'true' understanding of history.

The discontent with modern history writing is a consistent theme in "Fraser's Magazine" throughout the 1850 s, 60 s and 70 s, and the demand which unites the contributors, articles and centuries is a seemingly simple one: truth. ${ }^{28}$ The emphasis on the truthfulness of the 'perfect' historian's account reoccurs in all articles dealing with contemporary history writing and is turned into the key characteristic. Nevertheless, it is never specified what the standard for the truthfulness of a historical account is and how a 'true' historian might be recognised. The term is simply used as an abstract concept which distinguishes the 'good' from the 'bad'. However, the contributors are all in agreement that it is this truthfulness that constitutes the ideal historian and that it is this quality which accounts for their writing showing the 'real past'. Thus, a review of Forster's work on Charles I praises him as a good example for portraying the "real character [...] of our history and [...] the nature of the men" and thus finds the book to be "solid and trustworthy". ${ }^{29}$ In another essay, Shirley contrasts an incompetent and a good historian and states:

"[A good historian] is an infinitely truer student of life, an infinitely more reliable observer of the past. [...] the one paints with inimitable grace the face; the other, though in a somewhat rough way, dissects the heart. The one is superficially accurate and picturesque, the other is true to the core. The one stops outside, and, microscope in hand, examines with immense attention the coat: the other pierces into the life." 30

The abstract concept of truth accordingly seems to lie beneath the surface. While the mediocre historian will only look at the "outside", the ideal historian will "pierce into" life. While the one account is "accurate", yet only "superficially", the other one is "true to the core" and "dissects the heart". ${ }^{31}$ It seems to be not only a

27 Though of course the assessment of what is 'really' relevant in a history book was a fact neither then nor today, and thus there can be no right or wrong in answering this question.

28 Of course, there are also reviews of history books to be found which show contemporary historical works in a favourable light, but nevertheless they always include points of criticism, and whenever history writing is discussed in general, on a theoretical level, discontent is the driving force. The only exceptions are reviews of history books written by James Froude and Arthur Helps, both of whom were writing for "Fraser's", Froude even being its editor between 1860 and 1874. Notably, however, their books are not dealt with theoretically and are not used as an example for a general standard or to design an ideal. Mayflowerings, in: Fraser's Magazine, November 1864, p. 549.

30 Shirley, The Sphynx. A Discourse on the Importance of History, in: Fraser's Magazine, July 1861, pp. 68-69.

31 Ibid. 
question of getting the facts straight, since the works being criticised are "accurate" yet not considered of high quality, but a question of depth and intensity. The 'true' historian does not look at history as a dead past, but as alive, and apparently is even able to enter it, "pierce into the life". ${ }^{2}$ Therefore, there seems to be a distinction between a dead, factual past and a description which reinvigorates the past, recreates its life and thus is considered more true and real. He is, as Shirley points out, "the historian who rehabilitates in flesh and blood the dry bones ${ }^{33}$ of the past". ${ }^{34}$ The difference between 'good' historians and those criticised therefore apparently lies in the way they relate to the past, or even in their relationship to the past. Thus, the ideal historian seems to stand in direct contact with the time he describes and therefore is able to paint a picture of 'how it really was'.

Here the connection to Carlyle and his views on heroism can be found, as the ability of seeing, knowing and conveying the truth to others was one of the key characteristics of a Carlylean hero. ${ }^{35}$ This central argument of Carlyle as well as the attributes of 'his' heroes are taken up and used by the contributors to describe their ideal historian: The model historian is "truthful", ${ }^{66} \mathrm{he}^{37}$ possesses "marvellous insight", ${ }^{38}$ is "a seer", ${ }^{39}$ in short a "genius". ${ }^{40}$ Carlyle believes that "great men", ${ }^{41}$ "earnest, truthful kind of men", 42 "want to know; to get into the truth of anything" ${ }^{43}$ Only the hero, Carlyle believes, can perceive the "genuine essence of truth" 44 and with this knowledge guide people towards "truth and reality". ${ }^{45}$ Thus, not only are the keywords for the description of the hero reused for the description of the ideal historian in "Fraser's Magazine" but the correlation of their function also becomes obvious: While the Carlylean hero acts as a "bringer back of men to reality" ${ }^{46}$ for the present time, the historian performs the same function for the past. He thus is a 'bringer back of reality to men'. By truthfully reinvigorating the reality of the past, the ideal historian is thus turned into a hero of the past.

The question remains as to how the abstract, mythical portion of the demanded truthfulness is to be achieved. In explaining this, the articles employ

32 Ibid.

33 The reinvigoration of dry bones is a phrase which is taken up in several of the articles dealing with history writing.

34 Shirley, The Sphynx (footnote 30), p. 68.

35 Carlyle, On Heroes (footnote 23), p. 104.

36 G. H. Lewes, Carlyle's Frederick the Great, in: Fraser's Magazine, December 1858, p. 631.

37 In the following, I will only refer to the historian as a "he" since no article mentions a female history writer or regards even the possibility of there being one.

38 H., Thoughts on Modern English Literature, in: Fraser's Magazine, July 1858, p. 97.

39 Shirley, The Sphynx (footnote 30), p. 67.

40 Lewes, Carlyle's Frederick the Great (footnote 36), p. 631.

41 Carlyle, On Heroes (footnote 23), p. 175.

42 Ibid., p. 43.

43 Ibid., p. 52.

44 Ibid., p. 56.

45 Ibid., p. 111.

46 Ibid., p. 119. 
Carlyle's rhetoric. Thus, the semantic field of seeing, which recurs in all of Carlyle's lectures on heroism, is projected as an omnipresent basic characteristic of his hero. A 'great man' necessarily has to perceive the world differently from 'ordinary' men; he needs a different vision, needs to be a "seer". ${ }^{47}$ So does Carlyle describe the hero in his second lecture as someone who "looks through the shews of things into things", ${ }^{48}$ who has an "eye that flashes direct into the heart of things, and sees the truth of them" ${ }^{49} \mathrm{He}$ describes Shakespeare as possessing the "seeing eye" 50 and the heroic priest as having "an eye for [...] the unseen Heaven". ${ }^{1}$ The sceptics of the $18^{\text {th }}$ century, whom he considers a hindrance to the emergence of heroes, are called "eyeless", 52 the Marquis Mirabeau on the other hand a man "of true insight, superiority of vision". ${ }^{3}$

The same use of words can then be found in the articles in "Fraser's Magazine" dealing with the question of history writing. The words used by Carlyle to describe his heroes are in this context attributed to the ideal historian the authors describe or imagine. Thus, this 'good' historian has "marvellous insight [...] into the secret chambers of the human heart". ${ }^{54}$ The ideal historian is described as "a seer" ${ }^{55}$ who "pierces into the life, noting the coat also as it passes and finding something even there which had somehow eluded the eye of the other". ${ }^{56}$ The historian is a "good man and true, prophet and poet, with far-seeing eye, with heart alive to all noblest resonances, and with lips touched with most authentic fire". ${ }^{57}$ Another contributor describes the ideal historian as "look [ing] about him with eyes absolutely clear and honest" 58 and being "enabled [...] to see the past, [...] to behold the actors as they lived and suffered, to make all the crowded scene visible to every spectator". ${ }^{99}$ These words are used and reused in all articles dealing with the state of history writing, and by echoing Carlyle's wording the articles already place the ideal historian in the realm of the Carlylean hero.

To Carlyle's semantic of seeing the articles add the Promethean feature of light. One article distinguishes the incompetent historians from those who "throw more light on the real character" of history. ${ }^{60}$ It is stated that the ideal historians
Ibid., p. 104.
Ibid., p. 49, emphasis mine.
Ibid., p. 61, emphasis mine.
Ibid., p. 94, emphasis mine.
Ibid., p. 103, emphasis mine.
Ibid., p. 155, emphasis mine.
Ibid., p. 171, emphasis mine.
H., Thoughts on Modern English Literature (footnote 38), p. 103, emphasis mine.
Shirley, The Sphynx (footnote 30), p. 67, emphasis mine.
56 Ibid., p. 69, emphasis mine.
57 Helps's Spanish Conquest in America (footnote 25), p. 243, emphasis mine.
58 A. Lang, Carlyle’s Reminiscences, in: Fraser's Magazine, April 1881, p. 520, emphasis mine.
59 Ibid., p. 526, emphasis mine.
60 Mayflowerings (footnote 29), p. 540, emphasis mine. 
"emit the flashes of light which reveal the heart" of history ${ }^{61}$ or "put [a historical] fact in a striking light". ${ }^{62}$ The phrase of throwing or shedding light upon something is repeated numerous times in relation to history writers and sometimes even occurs several times in one article. ${ }^{63}$ Thus, the historian is established as a bringer of light, a promoter of knowledge who makes things visible to others, which then ties in with the historian's function as a 'seer'.

Hence, the ideal historian as developed in "Fraser's Magazine" is built along the lines of Carlyle's concept of heroism. Both possess an eye superior to that of other men, both see more or differently, and additionally, both have an educative, reformatory function. They do not want to keep their superiority for themselves but want to share it with others. The historian's sincere mission is thus to bring the figurative light of knowledge to others, to teach them the truth only he can see and thereby enlarge the public's field of vision and show it the reality of the past.

However, the analogy does not stop at this point. In addition to the functions stated above, both the Carlylean hero and the ideal historian are said to perform the role of a moral leader. Carlyle, for example, describes his hero as possessing "true morality", ${ }^{64}$ as being "morally great, above all". ${ }^{65}$ This, for him, is also linked to the intellectual and spiritual insight of the hero, since "without morality, intellect were impossible" 66 and "a thoroughly immoral man could not know anything at all". ${ }^{67}$ Also, there is "much morality [...] in the kind of insight" 68 the hero possesses. Therefore, both the rational and the spiritual characteristics which distinguish the hero from others and elevate him morally are united in the ideal historian in "Fraser's Magazine". So does Shirley relate that "a sound analytic faculty implies not only an imaginative, but a moral guidance". ${ }^{69}$ Another author cites "moral excellence" 70 as a characteristic of the hero-historian, and yet another calls him the "advocate of a great moral revolution". ${ }^{71}$ Shirley even goes as far as to state that "no historian, therefore, can be really great who is not at once a poet and a moralist". 72 This quote then not only affirms the historian's role as a moral guide but leads us to a further analogy between hero and historian - the poetic quality.

61 Shirley, The Sphynx (footnote 30), p. 76.

62 Mayflowerings (footnote 29), p. 542.

63 To give only a few examples: Lewes, Carlyle's Frederick the Great (footnote 36), p. 648; Mr. Carlyle, December 1865, three times; Edward Gibbon, October 1852, p. 438; Mayflowrings (footnote 29), p. 550. Carlyle, On Heroes (footnote 23), p. 51.

Ibid., p. 85.

Ibid., p. 95.

Ibid.

Ibid., p. 84.

Shirley, The Sphynx (footnote 30), p. 68.

Lewes, Carlyle's Frederick the Great (footnote 36), p. 542.

71 Edward Gibbon (footnote 63), p. 445.

72 Shirley, The Sphynx (footnote 30), p. 68. 


\section{Disseminating Truth - the Poetic Qualities of the 'Hero-Historian'}

Carlyle's statement that all 'types' of heroes are connected through their use of writing and the poetic quality of this writing ${ }^{73}$ also holds true for the ideal historian as presented in "Fraser's". Almost all articles stress this fact and emphasise that it distinguishes a good from a mediocre or even bad history writer. One contributor, for example, states that "[p]oetry, indeed, is not history, nor is history poetry; and yet it is eternally true that, except by a poet, no perfect history can be written" ${ }^{74}$ Further, the work of the perfect historian is characterised as possessing the "serious and literal fidelity of Dante" 75 and thus not only moves him into a poetic context by comparing him to the literary figure but with this comparison also places him in the realm of Carlyle's heroes, since Dante is one of the two examples Carlyle gives for his 'hero as poet'. Numerous times, the historian is called a poet, his writings are aligned with works of literature and his literary qualities are stressed.

Again, this attribution performs two functions. On the one hand, the qualities are described in their effect on the reader when one contributor states that "this way of writing [...] is incomparably the liveliest and most instructive method that can be followed". ${ }^{76}$ Thus, one aim of the poetic quality of the historian should be to convey a historical event in a fashion which is both instructive for the audience and gives the readers a lively and 'authentic ${ }^{977}$ impression of the topic. On the other hand, the poetic quality, as described by the contributors, is also connected to the abstract idea of the historian having superior insight, being able to see the truth and reality of the past. The historian "who rehabilitates in flesh and blood the dry bones of the past must be not only an antiquary but a poet" ${ }^{78}$ and thus it is the poet in the historian who is able to connect to the reality of the past and form the mythical, spiritual bond which makes him reinvigorate it.

It is not surprising that a similar passage can be found in Carlyle's lecture on heroism. Already in his first lecture on the Scandinavian pagans, he calls them "poetic minds"79 and relates them to the poet's extraordinary position in contemporary society. When praising the pagan's ability to see through the superficialities of life, he states that "in such a time as ours it requires a [...] Poet to teach us [this]" ${ }^{80}$ Carlyle believes that "the ancient earnest soul" ${ }^{81}$ does still live inside

Cf. Carlyle, On Heroes (footnote 23), p. 143.

H., Thoughts on Modern English Literature (footnote 38), p. 103.

Lewes, Carlyle's Frederick the Great (footnote 36), p. 539.

Mayflowerings (footnote 29), p. 540.

I use the word authentic in this context in an equally abstract way as the authors in "Fraser's Magazine", thereby referring to what they consider to make the historian's work convey 'reality' and 'truth'.

Shirley, The Sphynx (footnote 30), p. 68.

Carlyle, On Heroes (footnote 23), p. 5.

Ibid., p. 8. 
some men and that "we still honour such a man; call him Poet, Genius and so forth". ${ }^{82}$ It is thus the poetic quality in the contemporary hero which makes him see the world as it is. Consequently, every hero is necessarily a poet. By attesting the ideal historian's poetic qualities and relating them to his mythical connection to the past, he is even more strongly related to the Carlylean hero. Thus, the hero-historian can be seen as one of the "ancient earnest soul[s]", 83 thereby strengthening his connection to the past and further elevating him.

However, the historian in "Fraser's Magazine" is not described as a 'mere' poet but even granted the position of a genius. It is pointed out that "it is only Genius that will undergo this labour [of writing a good history book], because it is only Genius that can feel this need"; 84 furthermore, "nothing but native genius could have enabled him [the true historian] to see the past as he did". ${ }^{55}$ Shirley states that "it requires a man of original and independent genius - a man who, by an imaginative logic, can put together the shattered fragments and the scattered $d e-$ bris [of history] - to prevent the restoration from becoming a monument of incongruities". ${ }^{86}$ Thus, the genius-idea is used as a further attempt to explain the abstract concept of the connection between historian and past. However, it also individualises the historian and elevates him further, since only a historian with "imagination of such extraordinary power [...] is endowed with such a marvellous faculty for making dry bones live". ${ }^{77}$ Accordingly, one article points out that the work of the historian - in this particular case the author is referring to Carlyle and Michelet - in its complexity cannot be conducted by anyone: "It is true that Carlyle in England, and Michelet occasionally in France, have adopted a manner very different from their predecessors; but Carlyle is a man sui generis, and therefore a most unsafe model for any one to follow." 88 Thus, it is the genius historian who is able to produce a 'real' work on history, be it due to the workload (see quote above) or due to his sui generis qualities, and it is only a genius who can follow in his steps. The 'normal' man remains a recipient and is dependent on the genius historian if he wants to enter the realm of 'real' history.

Needless to say, Carlyle touches upon the concept of the genius as well in his lectures on heroism. Thus, he refers to the genius of his protagonists at various points in the lectures, speaks of their "poetic genius" or the "light of genius", and further points out that contemporary society does not have a fixed term anymore for what he calls a hero when he says "for what we call 'originality,' 'sincerity,'

81 Ibid.

82 Ibid., p. 19.

83 Ibid., p. 8.

84 Lewes, Carlyle's Frederick the Great (footnote 36), p. 631.

85 Lang, Carlyle's Reminiscences (footnote 58), p. 526.

86 Shirley, The Sphynx (footnote 30), p. 68.

87 Mayflowerings (footnote 29), p. 540.

88 Palgrave's History of Normandy and of England, in: Fraser's Magazine, July 1851, p. 2. 
'genius,' the heroic quality we have no good name for". ${ }^{89}$ Thereby, he makes it clear that 'genius' is a, yet in his opinion insufficient, synonym for what he identifies as a hero, "a man of 'genius' as we call it". By making his genius a key characteristic of the historian, he is therefore once more turned into a modern Carlylean hero. ${ }^{90}$

It has thus become clear that the idea of the ideal historian as developed in "Fraser's Magazine" is constructed in accordance with Thomas Carlyle's concept of the hero. The contributors achieve this by giving the historian similar qualities as Carlyle's heroes: he can see more clearly than other men, has insight denied to others and thus is able to perceive and understand the 'truth' and 'reality'. These qualities of the hero are then shifted backwards in time so that the historian is, in contrast to Carlyle's heroes, not a "seer" through the "shews" 1 of contemporary life, but a seer of the past. His special, mythical, almost spiritual connection is one to the past. Both hero and historian have a didactic, reformatory function and see it as their task to bring their knowledge to others, share their vision with those who do not possess the genius to see it themselves. Their poetic quality enables them both to access the 'reality' and to convey their insight to others. Thus, the historian, who has to be seer, genius, poet and moral guide at once, can be considered a modern Carlylean hero whose reference point of insight has been shifted to the past. ${ }^{92}$

Since the authors of "Fraser's Magazine" construct their ideal historian as a Carlylean hero, one might wonder how Carlyle himself surfaces in these articles. Although the analogies between the historian and Carlyle's hero concept are so striking, none of the articles draws a direct connection to Carlyle's views on heroism. However, all the articles cited above, and many others on the topic of history writing, do not only fashion their ideal historian as a hero, but also give him a name: Thomas Carlyle. They thus establish the connection to Carlyle's works and views by making him the prime example and representative of an ideal historian. By bringing up Carlyle again and again as the ideal historian and describing him with the categories of his own work, they indirectly evoke his lectures on heroism. They thus reaffirm Carlyle's views in connection to contemporary history writing twice, first by designing the ideal historian as the Carlylean hero, and second by turning Carlyle himself into a hero of his own kind.

Furthermore, this offers a glimpse at what the contributors would expect their audience to know. It can be presumed that the audience was expected to understand the reference to Carlyle's "On Heroes, Hero-Worship and the Heroic in His-

89 Carlyle, On Heroes (footnote 23), p. 139.

90 'Modern' in that the hero historian is positioned in and influenced by modern society, which also explains him being considered a genius so often.

91 Carlyle, On Heroes (footnote 23), p. 104.

92 Carlyle himself also described his heroes as being able to connect past and present, cf. Carlyle, On Heroes (footnote 23), p. 143. 
tory", thereby emphasising its cultural significance strongly. ${ }^{93}$ The demand for the hero-historian can thus be seen as a revolt against the new, secular, scienceoriented, and increasingly democratised way of conducting affairs which developed in the second half of the $19^{\text {th }}$ century. Though the Chartists' efforts in the 1840s did not result in an effective change, the idea of granting political rights to members of all classes of society continued to circulate in public discussion and led to a Parliament reform in 1867. The Second Reform Act extended the right to vote to all householders as well as lodgers who paid rent of $£ 10$ a year or more. Although this change would only have affected middle-class men, it led to a change in public perception and continuing political demands of the working classes. After almost two more decades, in 1884, the Third Reform Act finally granted universal franchise - to men. It is this climate of political change and the loudening voice of the middle and working classes that the articles discussed above fall into. Apart from this opposition, the articles can also be read as an attempt to fight the lack of orientation after Darwin - by placing modern society in a longer historical narrative. After the realisation that "nature propagates species and is careless about individuals", ${ }^{94}$ the disorientation led in some parts of society to a growing demand for a guiding figure, an individual, a hero who would unite the divided society and show the confused and disoriented people what truth, what reality really is.

Though some authors comment upon the difficulty to adapt Carlyle's views to modern times and, for example, acknowledge the threat that a charismatic, powerful leading figure in politics can be to a society, ${ }^{95}$ this is always elegantly counterbalanced. For example, the religious focus of Carlyle's concept is clearly seen as not adaptable to the second half of the $19^{\text {th }}$ century, but this fact is then presented as the natural continuation of Carlyle's lectures. While the heroes, at least in his lectures, start out as god-like and 'end' as secular kings, the nonreligious hero in an increasingly secular society is seen as a logical continuation of this development. And although the criticism, quietly voiced as it may have been, reflects the general developments in Victorian society (which leave Carlyle a mere theorist), solidarity from the contributors' side towards Carlyle can always be perceived. Thus, every argument against him is counterbalanced by praise of other qualities of his work. Carlyle is, through the decades, used as a reference point for authors looking for support in social and political matters.

93 Interestingly, the commercial aspect of history writing is not dealt with in any of the articles. Though Carlyle himself points to this issue when speaking about the Man of Letters as a hero, the contributors to "Fraser's" do not reflect upon the mechanisms of the print market, in which both the authors of history books as well as the periodical writers themselves are involved.

94 O. Chadwick, The Secularization of the European Mind in the Nineteenth Century, Cambridge 1975, p. 253.

95 Thus, for example, the contributor J. V. states that many "great men [set] to work as agitators and revolutionists to sow discontent and add to the difficulties of those who are responsible of maintaining public order”, J. V., Is Monarchy an Anachronism?, in: Fraser's Magazine, October 1875, p. 413. 
To summarise, the treatment of Carlyle in "Fraser's Magazine" falls short of the developments in British society. This can, on the one hand, be related back to Carlyle's own involvement in the early phase of the magazine. Since he himself partially shaped the profile of the magazine and his own political and social values were so much in accordance with those which the magazine propagated, a criticism of Carlyle could have been considered a criticism of the magazine at the same time. Though the contributors did not fully support Carlyle's theories in the end and did not feel that heroes were per se still necessary in the modern world, they still held on to their 'personal hero' Carlyle. Similarly, the magazine in general had lost touch with the demands of the readers: having started out in the 1830 s as a periodical which was designed against other competitors on the market, this 'being other than'-mentality was at the heart of the magazine's selfconception in the first, successful decades and seemed to have remained the focal point of reference in the time after the charismatic leaders had died. The periodical held on to this myth of the early years, neglecting the changing demands of the contemporary print market.

The articles discussed above serve as examples of this: By maintaining the format of long, political, conservative, and essentially elitist essays, the magazine set itself against contemporary society and tried to evoke a worldview which no longer correlated with the public perception of the world. The class for which the traditional content might still have been relevant, upper-class intellectual conservatives, may still have been at the fore in Parliament but had had to accept that they could not act as a leading caste which the rest of the country would follow. The middle classes were growing in importance, not only politically through the reforms mentioned above but especially by virtue of their increasing power on the consumer market. And a periodical like "Fraser's" and the concept of heroism it presented was, judging by the circulation numbers, not what the average consumer was looking for.

The publication's high point in circulation had been 8,000 copies in the 1840 s, a success at the time but a number that could not stand up to those of popular magazines, which often had a circulation of between 100,000 and 500,000 copies. "Fraser's" clung to the idea of elitist specialised content at a high price for an exclusive readership, while other journals provided substantiated information as well as entertainment at cheap prices and, importantly, recognised the middle classes as a target group with both monetary as well as societal and political potential. Interestingly, this more democratised and egalitarian view of society also resulted in a different representation of the heroic in other periodicals of the time (which can be called popular due to their high circulation figures). In publications such as "The Leisure Hour", "Chambers's Journal" or "All the Year Round", heroism is not only something to be admired by the middle and working classes but something they can achieve themselves. Just as the middle classes in society seem to have taken up a portion of the upper classes' dominance, the concept of the 
Carlylean hero has been replaced by a more 'common' hero who serves as a role model and inspiration for others rather than a messiah.

"Fraser's", then, came to experience the main power of its audience - they stopped consuming. Thus, the magazine was down to a run of 500 copies in 1880. It had become too intellectual, theoretical and backwards-looking and, interestingly, the very last issue of the magazine programmatically contains almost only articles which trace history of some kind, be it of agricultural terms, the art of biography writing, or English philology. All of them state clearly that tradition should be favoured over the new, and the essay on English philology, which opens the last number, closes with the statement that the work of a real "man of letters" - again a term frequently employed by Carlyle as well - has its retribution beyond "mention in a price-list and market value". ${ }^{96}$ Thus, keeping in mind the utterance by Knowles that "an old thing cannot be revived - never has been", 97 it is clear that both Carlyle's theories and the magazines had fallen behind the times and that not only could Carlyle's concept of heroism not be considered timely, but "Fraser's" itself was not able to adapt to the environment around it anymore.

In November 1882, one month after "Fraser's" discontinuation, "Longman's", the magazine's supposed successor, was launched. However, when looking at the table of contents of the first issue, almost no resemblance to "Fraser's" can be found. The sober design of "Fraser's", the focus of which had only ever been on the printed word, is replaced by floral ornaments. Instead of 20-30 page long essays and political opinion pieces, the reader is presented with three serial novels. And if one looks for Thomas Carlyle's name - it can merely be found in advertisements under the heading "Memories, Reminiscences etc."

96 English: Its Ancestors Its Progeny, in: Frasers Magazine, October 1882, p. 457.

97 Qtd. in Houghton, The Wellesley Index (footnote 1), p. 315. 
